\title{
AN ANALYSIS OF FOREST FIRE HISTORY ON THE LITTLE FIREHOLE RIVER WATERSHED, YELLOWSTONE NATIONAL PARK
}

Dennis H. Knight and William H. Romme

Botany Department, University of Wyoming

\section{Objectives}

Fire is now recognized as a major ecosystem process and Yellowstone National Park has recently implemented a fire management plan that permits lightning fires to burn without interference under certain conditions. To predict the kinds of wildfires we can now expect in the Park, and to evaluate the effectiveness of this plan in restoring fire to the Yellowstone ecosystem, it is important to know the natural frequency and size of wildfires under pristine conditions. This study, which began in 1977 and will be completed in June 1979, has the following objectives: (1) to determine the incidence and size of major fires during the last 300-400 years on the $100-\mathrm{km}^{2}$ Little Firehole River watershed, an area dominated by extensive lodgepole pine and some spruce-fir forests; (2) to determine average fire frequency, i.e., the time interval between successive major fires on any particular site; and (3) to determine the relationships between stand age or successional stage and fuel accumulation or the probability of fire.

\section{$\underline{\text { Procedures }}$}

The fire history is being constructed with the method outlined by Arno and Sneck (1977). Fire-scarred trees are located and sectioned, and fire years are determined by counting the annual rings from the cambium back to the scar. Reproduction of shade-intolerant species (in this case Pinus contorta) following fires is documented by taking increment cores from dominant individuals of all age classes present within a stand. Fuels were sampled with the planar intersect method (Brown 1974) in stands ranging from very young to very old in the two predominant habitat types (Steele et al. 1977) on the watershed. Other parameters of stand structure and site conditions that may influence fuel accumulation were also measured, such as infestation by insects or mistletoe and site productivity. The data will be examined for correlations between fuel accumulations and parameters of stand age, structure, and site. In addition, the fuels data will be used in a fire behavior model to further explore the relationships between stand age and flammability.

\section{Results}

Fieldwork was completed in September 1978, with a total of 93 stands sampled from all portions of the watershed. Fire-scar and increment core analysis will be completed soon, after which maps will be constructed to show present stand age and the extent of major fires in the past. 
Preliminary results indicate two very extensive burns on the Little Firehole River watershed during the last 400 years, as well as several less extensive burns. Most of the watershed has been burned during this time, although many areas, particularly at higher elevations and on sheltered sites, have no evidence of fire for at least 400-500 years. The two major fires, approximately 235 and 180 years ago, respectively, together covered about half of the $100-\mathrm{km}^{2}$ watershed, as well as adjacent areas outside the watershed. Apparently most major fires were stand-replacing crown fires, with non-stand-replacing surface fires covering much smaller areas. Firescarred trees are frequently found, but they always occur in small patches and appear to represent the margins of destructive crown fires rather than being indicators of extensive sweeping surface fires.

Most major fires on the Little Firehole River watershed occurred during the eighteenth and early nineteenth centuries, with very few fires during the last 130 years. This recent decline in fires cannot be attributed solely to fire suppression by man, however, because Park records show very few lightning ignitions in this portion of the Park since its establishment in 1872. A more plausible explanation may be that stand conditions have not yet become suitable again for a major fire in most of the area since the extensive burns 130-230 years ago. This hypothesis will be explored further when data analysis is complete.

Fuel data from 17 stands have been summarized and analysis has begun. The stands range in age from 29 to $550+$ years. There are no statistically significant differences in small dead woody fuels (0-3 inch diameter) related to either stand age or habitat type, although there is a general increase in heavy fuels (greater than 3 inches diameter) with increasing stand age, and live fuel biomass (shrubs and herbs) is greater in the more mesic Abies lasiocarpa-Vaccinium scoparium habitat type than in the more xeric: Pinus contorta-Carex geyeri habitat type (Steele et al. 1977). A more detailed analysis of these relationships will be made later this winter.

Fuels data from two representative stands were used in Rothermel's (1972) fire behavior model. Analysis of the results is not yet complete, but the model predicts generally low fire intensities and rates of spread. Fuel data from all 17 stands will also be applied to the national firedanger rating system model (Deeming et al. 1978).

\section{Conclusions}

Two major fires and several less extensive fires together burned over most of the $100-\mathrm{km}^{2}$ Little Firehole River watershed during the last four centuries. The vegetation today is dominated by lodgepole pine forests of various ages that became established following these fires. The most extensive burns occurred between about 1740 and 1840 , with very few fires during the last 130 years. The reason for this recent decline in fires may be that fuel and stand structure characteristics have not yet become suitable for fire again since the extensive burns 130-230 years ago. The analysis to date has not identified the specific fuel or structure characteristics contributing to the apparent reduced flammability of younger forest stands, but further analysis is planned. The results thus far tentatively suggest that on this 
watershed extensive, destructive fires occur cyclically every 200-300 years, with a comparatively fire-free interval between periods of major fires.

\section{Acknowledgments}

Yellowstone National Park biologists Don Despain, Douglas Houston, and Mary Meagher provided valuable assistance and suggestions. Philip White, Larry Van Dusen, and Richard Levinson assited with field data collection, and Richard Levinson further assisted with aerial photography interpretation. James K. Brown of the U. S. Forest Service's Northern Forest Fire Laboratory generously assisted by applying our fuels data to the Rothermel fire behavior model. The staff of the 0ld Faithful Ranger Station arranged for extended stays in the back-country. The use of a trailer and supporting facilities at 0ld Faithful, provided by the Northern Rocky Mountain Parks Studies Cooperative Program and Yellowstone National Park, was greatly appreciated.

\section{Literature Cited}

Arno, S. F., and K. M. Sneck. 1977. A method for determining fire history in coniferous forests of the mountain west. USDA For. Serv. Gen. Tech. Rep. INT-42.

Brown, J. K. 1974. Handbook for inventorying downed woody material. USDA For. Serv. Gen. Tech. Rep. INT-16.

Deeming, J. E., R. E. Burgan, and J. D. Cohen. 1978. The national firedanger rating system -- 1978. USDA For. Serv. Gen. Tech. Rep. INT39 .

Rothermel, R. C. 1972. A mathematical model for predicting fire spread in wildland fuels. USDA For. Serv. Res. Pap. INT-115.

Steele, R., D. Ondov, S. V. Cooper, and R. D. Pfister. 1977. Preliminary forest habitat types of eastern Idaho and western Wyoming. USDA For. Serv., Intermountain For. and Range Exp. Sta. and Intermountain Region. 